\title{
Renal Clearance of Cystathionine in Homozygous and Heterozygous Cystathioninuria, Cystinuria, and the Normal State *
}

\author{
George W. Frimpter † And Abby J. Greenberg $\ddagger$ \\ (From the Departments of Medicine and Pediatrics, The New York Hospital-Cornell \\ Medical Center, New York, N. Y.)
}

\begin{abstract}
Summary. Cystathionine is more readily cleared from the plasma than other amino acids. This is because the amino acid has a very low tubular maximum $(\mathrm{Tm})$, in the order of $1 \mu$ mole per minute per 1.73 square meters body surface area (BSA). No essential differences in the reabsorption of cystathionine were observed in four normal subjects, two patients with homozygous cystathioninuria, one patient with heterozygous cystathioninuria, and one patient with cystinuria.

Apparent net tubular secretion of cystathionine was demonstrated in a child with homozygous cystathioninuria only after an intravenously administered load of lysine.
\end{abstract}

\section{Introduction}

Normally, only traces of cystathionine are found in human urine and plasma by ion exchange chromatography. A hereditary metabolic error characterized by abnormally high amounts of cystathionine in the urine has been reported in four patients (1-4). Increased cystathionine in the urine has also been reported in patients with tumors of neural tissue (5). In the first reported instance of familial cystathioninuria, the plasma cystathionine concentration was not demonstrated to be abnormally high by paper chromatography, the only technique available at the time (1). Plasma concentrations of cystathionine must nevertheless have been elevated in this patient because large amounts of the amino acid were subsequently

* Submitted for publication July 19, 1966; accepted March 6, 1967.

Supported in part by the following grants from the National Institutes of Health: AM-08404, HE-08736, and FR-47.

$\dagger$ Established Investigator, American Heart Association.

Address requests for reprints to Dr. George W. Frimpter, The New York Hospital-Cornell Medical Center, 525 E. 68th St., New York, N. Y. 10021.

$\ddagger$ Postdoctoral trainee in pediatrics (nephrology) supported by U. S. Public Health Service grant 5T1-AM$5455-02$ demonstrated in extracts of brain, liver, and kidney (6). In the three subsequent patients with cystathioninuria, ion exchange chromatography did indeed reveal increased plasma concentrations (24). In our laboratory, a previous study of amino acid renal plasma clearance in an adult with homozygous cystathioninuria had suggested tubular secretion of cystathionine (2). This study revealed a cystathionine excretion of 1.65 and 1.97 $\mu$ moles per minute in two collection periods with corresponding filtered loads of 1.46 and 1.65 $\mu$ moles per minute, respectively. These samples represented 13 and $19 \%$ more excretion than fil. tration and suggested renal tubular addition to the glomerular filtrate. Clearance of all other amino acids was normal (2). These findings suggested that the basic abnormality in cystathioninuria was dual, a high plasma concentration due to a metabolic "block" and renal tubular secretion.

As in other hereditary metabolic errors, identification of the heterozygous state in cystathioninuria poses a problem. If in the heterozygous state a slight increase in plasma concentration of cystathionine, natural or induced, leads to minimal or immeasurable increase in urine concentration because, as most amino acids are, it is almost completely reabsorbed in the tubule, then plasma 
concentrations might have to be determined. On the other hand, if nearly $100 \%$ of the substance were excreted, then examination of the urine for abnormal amounts of the amino acid would be both convenient and practical.

Cystathionine is an intermediate compound formed during the transfer of sulfur from methionine to cysteine. Its chemical structure is similar to that of the amino acids involved in cystinuria. Dent and Rose noted that these have two amino groups separated by four to six carbon atoms and suggested that they share a common reabsorptive pathway (7). However, these amino acids-cystine, lysine, arginine, and ornithine-do not seem to be involved in cystathioninuria (2). This is surprising, since infusions of lysine into normal subjects resulted in increased excretion of cystine, arginine, and ornithine $(8,9)$. That is, increased plasma cystathionine concentrations in homozygous cystathioninuria might be analogous in effect on cystine, arginine, and ornithine excretion to the infusion of lysine. In cystinuria, every plasma amino acid with the structural characteristics noted by Dent and Rose has been found to be excreted in excess. This includes the disulfides of L-cysteine and L-homocysteine (10) and of L-cysteine and D-penicillamine (11) and also citrulline $(12,13)$. Thus, it is surprising that excessive cystathionine is not excreted in cystinuria. Scriver has in fact observed one patient with cystinuria who had a peak in the cystathionine area of the urinary ion exchange chromatogram (14). The plasma concentrations, however, are normally so low that a slight increase in clearance could go unnoticed.

The purposes of this study are the following: first, to determine the mode of renal excretion of cystathionine in cystathioninuria; and second, to determine the renal plasma clearance of cystathionine in cystinuria in order to provide further information concerning the nature of the faulty mechanism.

\section{Methods}

Patients and subjects. The four normal subjects were young adult males recovering from unrelated illnesses. The adult and the child with homozygous cystathioninuria have been previously described $(2,4)$. The heterozygous subject was the child's mother (4). The adult male patient with cystinuria had had repeated surgery for cystine calculi but appeared to have no stones at the time of the study. He had grossly abnormal excretion of cystine, lysine, ornithine, and arginine. All subjects were maintained in a metabolic ward on a diet calculated to be constant in amino acid content. The patient with heterozygous cystathioninuria was given $1 \mathrm{~g}$ of L-methionine orally every 4 hours for 4 days before the clearance study to raise the plasma and urinary cystathionine to measurable concentrations.

Materials. The L-cystathionine infused into the normal subjects and the patient with cystinuria was purified from the urine of the adult with cystathioninuria by methods previously described (15).

The lysine given to the $10.7-\mathrm{kg}$ child with cystathioninuria was prepared as follows: $0.714 \mathrm{~g}$ of $\mathrm{L}$-lysine monohydrochloride was dissolved in $25 \mathrm{ml}$ of distilled water and buffered to $\mathrm{pH} 7.40$ by the addition of sodium bicarbonate. The final solution, which had an osmolality of $269 \mathrm{mOsm}$ per L, was autoclaved and administered intravenously over one 5-minute interval between the third and fourth clearance periods.

Procedure. After a priming dose, inulin was infused at a constant rate calculated to provide a plasma concentration of $25 \mathrm{mg}$ per $100 \mathrm{ml}$. A problem was encountered due to the poor solubility of cystathionine. Thus, 400 $\mathrm{mg}$ in $1 \mathrm{~L}$ of saline is a nearly saturated solution, and a good deal of solution must be infused to attain plasma concentrations approaching those in the patients with homozygous cystathioninuria. L-Cystathionine dissolved in saline was infused into two normal subjects at a rate of $9 \mu$ moles per minute beginning 1 hour before timed urine collection periods of 30 minutes each. In the third normal subject, cystathionine was first infused at a rate of $18 \mu$ moles per minute for 30 minutes, then at $7 \mu$ moles per minute for 20 minutes before beginning the first collection period and thereafter throughout the study. In the fourth subject, the amino acid was first infused at a rate of $32 \mu$ moles per minute for 20 minutes, then slowed to $18 \mu$ moles per minute 40 minutes before beginning the first collection period and continued throughout the study. These manipulations of flow rate were undertaken in two subjects to achieve a higher but relatively constant plasma concentration. In the patient with cystinuria, cystathionine infusion was begun after three control periods at a constant rate of $18 \mu$ moles per minute. Even though the plasma concentration would be increasing and thus not ideal for calculation of clearances, we felt that more meaningful data would be obtained by observing the clearance at different plasma concentrations. No cystathionine was infused into the patients with homozygous cystathioninuria or the patient in the heterozygous state. The homozygous patients were studied at their endogenous plasma concentrations. Plasma cystathionine concentrations of the patient with heterozygous cystathioninuria were not sufficiently elevated to permit easy measurement. Administration of $1 \mathrm{~g}$ L-methionine orally every 4 hours for 4 days before the clearance study increased the plasma concentration to measurable levels. Methionine and the asymmetrical disulfide of cysteine and homocysteine became measurable, and clearances of these are also reported. This dose 
of L-methionine does not similarly increase plasma cystathionine concentrations in normal subjects $(3,4)$.

Blood for amino acid and inulin analyses was obtained midway in the urine collection period. In all of the adults, 50-ml specimens were collected and the plasma was processed according to the method of Stein and Moore (16). In the child, $20-\mathrm{ml}$ specimens were obtained. Amounts of deproteinized plasma (5 to $10 \mathrm{ml}$ ) suitable to obtain good peaks were applied to the ion exchange columns.

The normal subjects and the patient with cystinuria were allowed to void on request. Urine from the patient with heterozygous cystathioninuria and the two patients with homozygous cystathioninuria was obtained via a soft rubber catheter with many holes. Samples of urine were promptly acidified and diluted in volumetric flasks for amino acid determinations. Specimens for analysis were stored at $-24^{\circ}$. All patients were given a water and saline load to ensure an adequate urine flow.

Analyses. Plasma and urinary amino acids were determined by the automatic ion exchange column chromatographic methods of Spackman, Stein, and Moore (17), as previously described in detail (18). Inulin was determined by the method of Schreiner (19) or Walser, Davidson, and Orloff (20).

\section{Results}

Normal subjects. The renal clearance of infused L-cystathionine in the four normal subjects is shown in Table I. (When the urine specimens were diluted so as to yield a good cystathionine peak, only a few of the amino acids normally found remained measurable.) In Subject 1, plasma cystathionine concentration did not exceed $1 \mu \mathrm{mole}$ per $100 \mathrm{ml}$. The renal tubular reabsorption ranged from 20 to $55 \%$. In Subject 2, plasma concentrations of 0.9 to $1.5 \mu$ moles per $100 \mathrm{ml}$ were obtained. When the plasma concentration was 1 $\mu$ mole per $100 \mathrm{ml}$ or more, less than $9 \%$ of the filtered load of cystathionine was reabsorbed. The inulin clearance in Subject 2 steadily decreased. It is possible that the recorded figure of $141 \mathrm{ml}$ per minute in period I was changing markedly within that period. The relatively constant fraction of glycine reabsorbed suggests, however, that the percentage of reabsorbed cystathionine was

TABLE I

Renal plasma clearances of cystathionine and glycine in four normal adult male subjects during L-cystathionine infusion

\begin{tabular}{|c|c|c|c|c|c|c|c|}
\hline Subject & Clearance period & $\mathrm{C}_{\mathrm{In}} *$ & Amino acid & Plasma & Filtered & Excreted & Reabsorbed \\
\hline \multirow{4}{*}{1} & & $m l / m i n$ & & umoles $/ 100 \mathrm{ml}$ & & & $\%$ \\
\hline & I & 116 & $\begin{array}{l}\text { Cystathionine } \\
\text { Glycine }\end{array}$ & $\begin{array}{l}0.567 \\
18.5\end{array}$ & $\begin{array}{l}0.657 \\
21.5\end{array}$ & $\begin{array}{l}0.368 \\
1.18\end{array}$ & $\begin{array}{l}44 \\
94\end{array}$ \\
\hline & II & 112 & $\begin{array}{l}\text { Cystathionine } \\
\text { Glycine }\end{array}$ & $\begin{array}{l}0.898 \\
20.7\end{array}$ & $\begin{array}{c}1.00 \\
23.1\end{array}$ & $\begin{array}{l}0.806 \\
1.48\end{array}$ & $\begin{array}{l}20 \\
94\end{array}$ \\
\hline & III & 107 & $\begin{array}{l}\text { Cystathionine } \\
\text { Glycine }\end{array}$ & $\begin{array}{l}0.969 \\
17.7\end{array}$ & $\begin{array}{l}1.04 \\
19.0\end{array}$ & $\begin{array}{l}0.469 \\
0.614\end{array}$ & $\begin{array}{l}55 \\
97\end{array}$ \\
\hline \multirow[t]{4}{*}{2} & I & 141 & $\begin{array}{l}\text { Cystathionine } \\
\text { Glycine }\end{array}$ & $\begin{array}{l}0.900 \\
21.3\end{array}$ & $\begin{array}{l}1.27 \\
30.0\end{array}$ & $\begin{array}{l}0.471 \\
0.659\end{array}$ & $\begin{array}{l}63 \\
98\end{array}$ \\
\hline & II & 117 & $\begin{array}{l}\text { Cystathionine } \\
\text { Glycine }\end{array}$ & $\begin{array}{l}1.00 \\
24.4\end{array}$ & $\begin{array}{l}1.17 \\
28.5\end{array}$ & $\begin{array}{l}1.16 \\
1.01\end{array}$ & $\begin{array}{r}1 \\
96\end{array}$ \\
\hline & III & 109 & $\begin{array}{l}\text { Cystathionine } \\
\text { Glycine }\end{array}$ & $\begin{array}{l}1.20 \\
24.9\end{array}$ & $\begin{array}{l}1.31 \\
27.1\end{array}$ & $\begin{array}{l}1.19 \\
0.950\end{array}$ & $\begin{array}{r}9 \\
96\end{array}$ \\
\hline & IV & 101 & $\begin{array}{l}\text { Cystathionine } \\
\text { Glycine }\end{array}$ & $\begin{array}{l}1.50 \\
25.6\end{array}$ & 28.5 & $\begin{array}{l}1.40 \\
0.835\end{array}$ & $\begin{array}{r}7 \\
97\end{array}$ \\
\hline \multirow[t]{3}{*}{3} & I & 86 & $\begin{array}{l}\text { Cystathionine } \\
\text { Glycine }\end{array}$ & $\begin{array}{l}3.26 \\
29.6\end{array}$ & $\begin{array}{l}2.80 \\
25.5\end{array}$ & $\begin{array}{l}2.40 \\
3.25\end{array}$ & $\begin{array}{l}14 \\
87\end{array}$ \\
\hline & II & 100 & $\begin{array}{l}\text { Cystathionine } \\
\text { Glycine }\end{array}$ & $\begin{array}{l}3.62 \\
25.7\end{array}$ & $\begin{array}{l}3.26 \\
25.7\end{array}$ & $\begin{array}{l}3.11 \\
2.82\end{array}$ & $\begin{array}{l}14 \\
89\end{array}$ \\
\hline & III & 86 & $\begin{array}{l}\text { Cystathionine } \\
\text { Glycine }\end{array}$ & $\begin{array}{l}3.84 \\
26.0\end{array}$ & $\begin{array}{l}3.30 \\
22.3\end{array}$ & $\begin{array}{l}2.86 \\
2.48\end{array}$ & $\begin{array}{l}14 \\
89\end{array}$ \\
\hline \multirow[t]{3}{*}{4} & I & 121 & $\begin{array}{l}\text { Cystathionine } \\
\text { Glycine }\end{array}$ & $\begin{array}{l}4.35 \\
22.1\end{array}$ & $\begin{array}{l}5.26 \\
26.7\end{array}$ & $\begin{array}{l}4.30 \\
2.90\end{array}$ & $\begin{array}{l}18 \\
89\end{array}$ \\
\hline & II & 102 & $\begin{array}{l}\text { Cystathionine } \\
\text { Glycine }\end{array}$ & $\begin{array}{l}6.65 \\
21.7\end{array}$ & $\begin{array}{l}6.79 \\
22.1\end{array}$ & $\begin{array}{l}4.28 \\
1.24\end{array}$ & $\begin{array}{l}37 \\
94\end{array}$ \\
\hline & III & 93 & $\begin{array}{l}\text { Cystathionine } \\
\text { Glycine }\end{array}$ & $\begin{array}{l}7.43 \\
23.2\end{array}$ & $\begin{array}{l}6.91 \\
21.6\end{array}$ & $\begin{array}{l}5.97 \\
2.07\end{array}$ & $\begin{array}{l}14 \\
86\end{array}$ \\
\hline
\end{tabular}

* Inulin clearance. 
higher in period I than in subsequent periods because the transport mechanism had not yet become relatively saturated. This saturation could occur at the luminal membrane, intracellularly, or at the nonluminal side of the cell, whichever has the limiting transport mechanism or mechanisms. In Subject 3, higher plasma concentrations were achieved, ranging from 3.21 to $3.84 \mu$ moles per $100 \mathrm{ml}$. Reabsorption was limited to $14 \%$ of filtered load. In Subject 4, there was a fall in urine flow and inulin clearance after the first period. However, the data are of value because still higher plasma concentrations of cystathionine were achieved, ranging from 4.35 to $7.43 \mu$ moles per $100 \mathrm{ml}$. In Table I, a limited reabsorption of cystathionine in the general range of that found in the normal subjects and in the various patients is again recorded. In comparison, although the filtered loads of glycine were about 3 to 20 times that of cystathionine, the former was more completely reabsorbed.

TABLE II

Clearance of cystathionine in an adult patient with homozygous cystathioninuria

\begin{tabular}{cccccc}
\hline \hline $\begin{array}{c}\text { Clearance } \\
\text { period }\end{array}$ & $\mathrm{C}_{\mathbf{I n}}$ & Plasma & Filtered & Excreted & $\begin{array}{c}\text { Re- } \\
\text { absorbed }\end{array}$ \\
\hline & ml/min & $\mu$ moles $/ 100 \mathrm{ml}$ & \multicolumn{2}{c}{$\mu$ moles $/ \min$} & $\%$ \\
I & 121 & 8.39 & 10.0 & 9.3 & 7 \\
II & 151 & 8.12 & 12.6 & 10.5 & 17 \\
III & 121 & 8.17 & 9.9 & 8.6 & 14 \\
\hline
\end{tabular}

Homozygous cystathioninuria-adult. The endogenous cystathionine clearance in the adult patient with homozygous cystathioninuria was characterized by a somewhat variable inulin clearance. Nevertheless, the plasma concentration of cystathionine always exceeded $8 \mu$ moles per $100 \mathrm{ml}$, and the amount of filtered cystathionine that was reabsorbed ranged from 7 to $17 \%$ (Table II).

Homozygous cystathioninuria-child. The plasma cystathionine concentrations measured in the 2-year-old child with homozygous cystathioninuria were about $3 \mu$ moles per $100 \mathrm{ml}$. During three control periods, the renal tubular reabsorption of cystathionine ranged from 7 to $20 \%$ of the filtered load, as shown in Table III. In contrast, although the plasma concentrations and filtered loads of glycine were over three times those of cystathionine, almost $98 \%$ of the glycine was reabsorbed.
TABLE III

Clearance of cystathionine in a 2-year-old male with homozygous cystathioninuria: effect of lysine infusion

\begin{tabular}{|c|c|c|c|c|c|c|}
\hline $\begin{array}{l}\text { Clear- } \\
\text { ance } \\
\text { period }\end{array}$ & $\mathrm{C}_{I_{n}}$ & $\begin{array}{l}\text { Urine } \\
\text { flow }\end{array}$ & Plasma & Filtered & Excreted & $\begin{array}{c}\mathrm{Re}- \\
\text { absorbed }\end{array}$ \\
\hline & \multicolumn{2}{|c|}{$\mathrm{ml} / \mathrm{min}$} & $\begin{array}{c}\text { pmoles / } \\
100 \mathrm{ml}\end{array}$ & \multicolumn{2}{|c|}{ 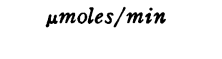 } & $\%$ \\
\hline I & 29 & 0.85 & 3.15 & 0.920 & 0.782 & 15 \\
\hline II & 30 & 0.90 & 3.08 & 0.932 & 0.868 & 7 \\
\hline \multirow[t]{2}{*}{ III } & 30 & 0.69 & 3.08 & 0.919 & 0.727 & 20 \\
\hline & \multicolumn{6}{|c|}{ Lysine infusion over 5 minutes } \\
\hline IV & 28 & 0.80 & 2.99 & 0.850 & 1.330 & -57 \\
\hline V & 19 & 0.46 & 3.10 & 0.589 & 0.603 & -2 \\
\hline
\end{tabular}

Although neither the plasma concentration nor the filtered load of cystathionine increased, the urinary excretion nearly doubled. The clearance ratio of cystathionine to inulin after the lysine infusion exceeded unity (1.6), indicating tubular secretion of cystathionine. Other amino acid concentrations did not change significantly. In a fifth clearance period, urine flow and inulin clearance fell, possibly owing to exhaustion and blood withdrawal. Plasma concentration of cystathionine, however, did not fall.

Heterozygous cystathioninuria. The results of the clearance study in the patient with heterozygous cystathioninuria are shown in Table IV. Clearances of methionine and of the asymmetrical disulfide of cysteine and homocysteine were also measured. In this patient, 15 to $34 \%$ of filtered cystathionine was reabsorbed, and 82 and $87 \%$

TABLE IV

Clearances of cystathionine, glycine, methionine, and the cysteine-homocysteine disulfide in an adult with heterozygous cystathioninuria after oral methionine loading

\begin{tabular}{|c|c|c|c|c|c|c|}
\hline Period & $\mathrm{C}_{\mathrm{In}}$ & Amino acid & Plasma & Filtered & $\begin{array}{c}\text { Ex- } \\
\text { creted }\end{array}$ & $\begin{array}{c}\mathrm{Re}_{-} \\
\text {absorbed }\end{array}$ \\
\hline \multirow{4}{*}{1} & $\begin{array}{l}\mathrm{ml} / \\
\mathrm{min}\end{array}$ & & $\begin{array}{c}\text { 4moles/ } \\
100 \mathrm{ml}\end{array}$ & \multicolumn{2}{|c|}{ нmoles/min } & $\%$ \\
\hline & 108 & Cystathionine & 1.62 & 1.75 & 1.15 & 34 \\
\hline & & Glycine & 18.5 & 20.0 & 0.626 & 97 \\
\hline & & Methionine & 22.1 & 23.9 & 0.245 & 99 \\
\hline \multirow[t]{4}{*}{2} & 93 & Cystathionine & 1.52 & 1.41 & 0.952 & 33 \\
\hline & & Glycine & 18.0 & 16.7 & 0.482 & 97 \\
\hline & & Methionine & 26.4 & 24.6 & 0.207 & 99 \\
\hline & & Disulfide* & 1.73 & 1.61 & 0.211 & 87 \\
\hline \multirow[t]{3}{*}{3} & 112 & Cystathionine & 1.54 & 1.72 & 1.46 & 15 \\
\hline & & Methionine & 24.5 & 27.4 & 0.269 & 99 \\
\hline & & Disulfide* & 1.60 & 1.79 & 0.319 & 82 \\
\hline
\end{tabular}

* Asymmetrical disulfide of cysteine and homocysteine. 
TABLE V

Clearance of amino acids in an adult patient with cystinuria before and during L-cystathionine infusion

\begin{tabular}{|c|c|c|c|c|c|c|c|}
\hline Period & $\mathrm{C}_{\text {In }}$ & Amino acid & Plasma & Filtered & Excreted & Reabsorbed & $\begin{array}{l}\text { Clearance ratio } \\
\text { Camino aoid/CIn }^{-}\end{array}$ \\
\hline & $m l / \min$ & & umoles $/ 100 \mathrm{ml}$ & \multicolumn{2}{|c|}{ 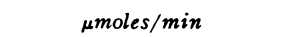 } & $\%$ & \\
\hline $\mathrm{I}$ & 71 & $\begin{array}{l}\text { Cystine* } \\
\text { Ornithine } \\
\text { Lysine } \\
\text { Arginine } \\
\text { Glycine }\end{array}$ & $\begin{array}{c}2.60 \\
3.70 \\
14.1 \\
5.80 \\
31.5\end{array}$ & $\begin{array}{c}1.86 \\
2.64 \\
10.0 \\
4.15 \\
22.5\end{array}$ & $\begin{array}{l}2.41 \\
1.04 \\
5.69 \\
3.20 \\
0.416\end{array}$ & $\begin{array}{r}-30 \\
60 \\
43 \\
23 \\
98\end{array}$ & $\begin{array}{l}1.3 \\
0.40 \\
0.57 \\
0.77 \\
0.02\end{array}$ \\
\hline $\mathrm{II} \dagger$ & 89 & $\begin{array}{l}\text { Ornithine } \\
\text { Lysine } \\
\text { Arginine }\end{array}$ & $\begin{array}{c}4.70 \\
13.8 \\
4.70\end{array}$ & $\begin{array}{l}4.21 \\
12.4 \\
4.21\end{array}$ & $\begin{array}{l}1.32 \\
7.41 \\
3.88\end{array}$ & $\begin{array}{r}70 \\
40 \\
8\end{array}$ & $\begin{array}{l}0.30 \\
0.60 \\
0.92\end{array}$ \\
\hline III & 66 & $\begin{array}{l}\text { Cystine } \\
\text { Ornithine } \\
\text { Lysine } \\
\text { Arginine } \\
\text { Glycine }\end{array}$ & $\begin{array}{c}2.50 \\
4.32 \\
12.1 \\
4.99 \\
31.7\end{array}$ & $\begin{array}{l}1.67 \\
2.89 \\
8.10 \\
3.33 \\
21.2\end{array}$ & $\begin{array}{l}2.15 \\
1.20 \\
4.58 \\
3.14 \\
0.490\end{array}$ & $\begin{array}{r}-29 \\
58 \\
44 \\
6 \\
98\end{array}$ & $\begin{array}{l}1.3 \\
0.42 \\
0.56 \\
0.94 \\
0.02\end{array}$ \\
\hline IV & 79 & $\begin{array}{l}\text { Cystathionine } \\
\text { Cystine } \\
\text { Ornithine } \\
\text { Lysine } \\
\text { Arginine } \\
\text { Glycine }\end{array}$ & $\begin{array}{c}3.10 \\
1.90 \\
4.30 \\
14.0 \\
4.50 \\
27.9\end{array}$ & $\begin{array}{c}2.48 \\
1.51 \\
3.44 \\
11.2 \\
3.59 \\
22.3\end{array}$ & $\begin{array}{l}1.61 \\
2.30 \\
1.36 \\
4.30 \\
3.94 \\
0.612\end{array}$ & $\begin{array}{r}35 \\
-53 \\
60 \\
38 \\
-10 \\
97\end{array}$ & $\begin{array}{l}0.65 \\
1.5 \\
0.40 \\
0.62 \\
1.1 \\
0.03\end{array}$ \\
\hline $\mathrm{V}^{\dagger}+$ & 76 & $\begin{array}{l}\text { Cystathionine } \\
\text { Cystine } \\
\text { Glycine }\end{array}$ & $\begin{array}{l}4.90 \\
2.20 \\
32.3\end{array}$ & $\begin{array}{l}3.74 \\
1.68 \\
24.7\end{array}$ & $\begin{array}{l}2.64 \\
2.35 \\
0.635\end{array}$ & $\begin{array}{r}30 \\
-40 \\
97\end{array}$ & $\begin{array}{l}0.70 \\
1.4 \\
0.03\end{array}$ \\
\hline VI & 67 & $\begin{array}{l}\text { Cystathionine } \\
\text { Cystine } \\
\text { Ornithine } \\
\text { Lysine } \\
\text { Arginine } \\
\text { Glycine }\end{array}$ & $\begin{array}{l}6.4 \\
2.20 \\
7.008 \\
15.7 \\
5.02 \\
29.8\end{array}$ & $\begin{array}{c}4.32 \\
1.49 \\
4.72 \\
10.6 \\
3.39 \\
20.1\end{array}$ & $\begin{array}{l}3.18 \\
2.17 \\
1.29 \\
6.48 \\
3.67 \\
0.517\end{array}$ & $\begin{array}{r}26 \\
-46 \\
73 \\
39 \\
-\quad 8 \\
97\end{array}$ & $\begin{array}{l}0.74 \\
1.5 \\
0.27 \\
0.61 \\
1.1 \\
0.03\end{array}$ \\
\hline VII & 71 & $\begin{array}{l}\text { Cystathionine } \\
\text { Cystine } \\
\text { Ornithine } \\
\text { Lysine } \\
\text { Arginine } \\
\text { Glycine }\end{array}$ & $\begin{array}{c}7.80 \\
2.60 \\
5.40 \\
16.2 \\
4.90 \\
31.0\end{array}$ & $\begin{array}{c}5.58 \\
1.86 \\
3.86 \\
11.6 \\
3.50 \\
22.2\end{array}$ & $\begin{array}{l}4.64 \\
2.61 \\
1.39 \\
5.78 \\
3.93 \\
0.594\end{array}$ & $\begin{array}{r}16 \\
-40 \\
64 \\
50 \\
-12 \\
97\end{array}$ & $\begin{array}{l}0.84 \\
1.4 \\
0.36 \\
0.5 \\
1.1 \\
0.03\end{array}$ \\
\hline
\end{tabular}

* "Cystine" figure represents cystine plus cysteine.

$\dagger$ Acidic and neutral amino acids not determined.

f Basic amino acids not determined.

$\$$ Value determined in triplicate.

of the asymmetrical disulfide was reabsorbed in two periods.

Cystinuria. The results of the cystathionine and cystine clearances obtained in the patient with cystinuria are shown in Table V. The plasma concentration of cystathionine increased from 3.1 to $7.8 \mu$ moles per $100 \mathrm{ml}$ during the infusion, and there was a concomitant progressive decrease in the tubular reabsorption of cystathionine from 35 to $16 \%$ as the filtered load increased. There was apparent net tubular secretion of cystine in all clearance periods in which it was measured. Before infusion of cystathionine, the clearance ratio of cystine to inulin was 1.3 , and during the infu- sion it was 1.4 to 1.5 . Cystathionine infusion did not alter the clearance of ornithine or lysine. (In period VI, the ornithine clearance ratio dropped to 0.27 , owing to an apparent isolated rise in the plasma concentration of ornithine that was confirmed by repeated chromatographies.) The clearance ratio for arginine/inulin increased to above unity during the cystathionine infusion. However, a progressive increase in the ratio began before the cystathionine infusion was started.

\section{Discussion}

These experiments demonstrate that the renal tubules could reabsorb far less cystathionine than 


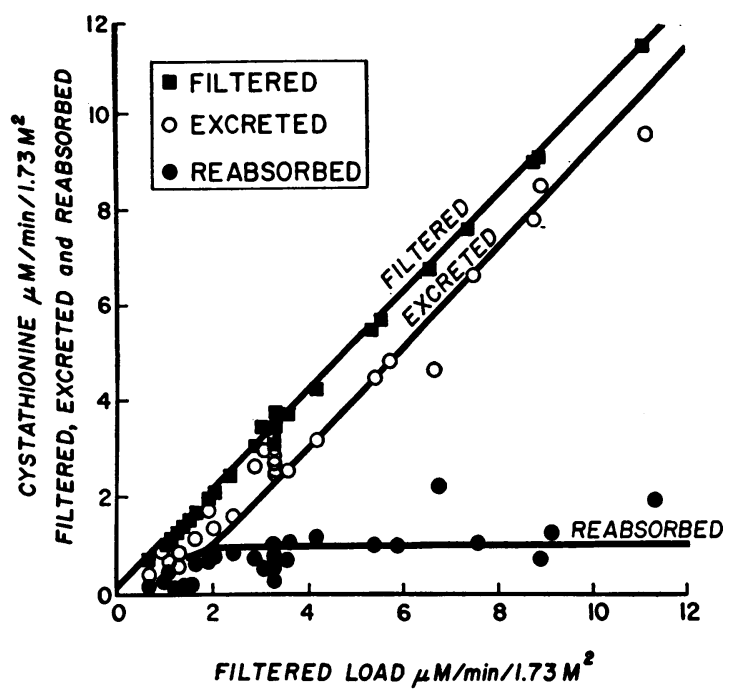

Fig. 1. Cystathionine data for all patients. Data are corrected to 1.73 square meters of body surface area. See text.

other amino acids in all subjects studied. Concentrations of plasma cystathionine beyond $1 \mu$ mole per $100 \mathrm{ml}$ were generally accompanied by reabsorption of less than $20 \%$ of the filtered load. . The data for all patients, shown in Figure 1, suggest a $\mathrm{Tm}$ for cystathionine reabsorption of about 1 $\mu$ mole per minute per 1.73 square meters BSA. Furthermore, some cystathionine is excreted at all filtered loads. This graph suggests that the mechanism of tubular reabsorption of cystathionine is not significantly different in normal individuals, subjects with heterozygous and homozygous cystathioninuria, and a patient with cystinuria. Tubular reabsorption of cystathionine is primarily related to the filtered load of this amino acid. Infusion of cystathionine did not result in abnormal excretion of other amino acids, notably of lysine, ornithine, or arginine. A somewhat lower reabsorption of glycine is recorded in Subjects 3 and 4 than in 1 and 2. However, this cannot be ascribed to cystathionine, since no control periods were obtained before the infusion. Also, the percentage of glycine reabsorbed remained relatively constant despite continued increase in plasma cystathionine concentration and filtered load. Therefore, no special significance can be attached to the glycine reabsorption except as a contrast to that of cystathionine. These data further suggest the probability that, in screening tests for cystathioninuria, examination of the urine will be adequate as opposed to the more difficult task of examining blood plasma.

The administration of lysine to the child with homozygous cystathioninuria was followed by apparent transient renal tubular secretion of cystathionine. Webber, Brown, and Pitts noted apparent secretion of cystine after lysine or ornithine infusion into dogs (21). The transient nature of this increased excretion was similar to that we have noted in our patient. Other studies in our laboratory have repeatedly yielded similar results in dogs given lysine during the course of a cystathionine infusion. The fact that excretion increased markedly without an increase in the filtered load suggests that the lysine had some effect on the renal tubular cells that induced net tubular efflux of cystathionine. The results are interpreted to indicate that net tubular efflux of cystathionine may occur under certain circumstances. Bidirectional movement of amino acids into and out of the tubular lumen may be a common phenomenon, with net tubular reabsorption existing under ordinary circumstances. Tubular reabsorption of amino acids is as an active process well established. Schwartzman, Blair, and Segal have shown a competitive efflux system for lysine, ornithine, arginine, and cysteine that is apparently different from the uptake system, which does not include cystine or cysteine (22). It is difficult to apply this type of mechanism to the present data. Rather, the data suggest a similarity to the demonstration of Goresky, Watanabe, and Johns that tritiated folic acid is released from renal tubular epithelial cells under the conditions of a load of nonradioactive folic acid (23). The present data bear no relationship to ordinary clinical circumstances. Reabsorption of cystathionine is different from that for cystine or lysine, arginine, and ornithine, even at the elevated plasma concentrations in homozygous cystathioninuria.

We failed to reproduce the apparent tubular secretion previously reported in the adult patient with homozygous cystathioninuria (2). At the time of the previous study, the patient had refused to eat the hospital diet and had lost weight. If the renal tubule is in any way conditioned to certain concentrations of cystathionine, tubular secretion may have occurred because of a recently lowered plasma concentration, a lowered filtered load, 
and decreased tubular reabsorption. If tubular transport is assumed to be normally bidirectional, then a tubular efflux which continues to be high owing to high intracellular concentrations might have resulted in net tubular secretion of cystathionine. This is speculation, since the results of the lysine infusion experiment herein reported do not help to explain the long term effects of dietetic alterations except to indicate that net tubular efflux is possible. After three control periods, this patient was given pyridoxine hydrochloride, $0.5 \mathrm{~g}$ intravenously, to determine whether this technique would disclose any acute effect on cystathionine transport. The lowering of plasma cystathionine concentrations in cytathioninuria after pyridoxine has been previously described $(2-4)$. No significant alteration in cystathionine clearance was noted.

The apparent tubular secretion of cystine in cystinuria has been reported in studies from this and other laboratories $(18,24)$. The finding of apparent tubular secretion in this patient was not anticipated, and plasma cysteine was not differentiated from cystine. Plasma specimens were, however, air oxidized to ensure chromatography of cysteine as cystine (16). The clearances of cystine, ornithine, lysine, and arginine probably did not change as a consequence of the cystathionine infusion. The clearance ratio for cystine changed only slightly, and the ratio for arginine was increasing before the infusion was begun. A patient prevously reported from this laboratory who exhibited apparent cystine secretion had a clearance ratio for arginine of 1.39 on one occasion and 1.0 on another (18). That patient, but not the present one, also had a defect for glycine reabsorption.

This study confirms the previous indication, obtained from studies of urinary amino acid composition, that cystathionine clearance is normal in cystinuria. Cystathionine appears, therefore, to be reabsorbed by a mechanism different from that for cystine, ornithine, lysine, and arginine. The theory of Dent and Rose that cystine, ornithine, lysine, and arginine are structurally similar, with two amino groups separated by four to six carbon atoms, seems to apply to cystathionine. Both cystine and cystathionine, however, differ from ornithine, lysine, and arginine in that sulfur links the carbon atoms between the amino groups.
Both cystine and the disulfide of cysteine and homocysteine have two sulfur atoms, so that a change in "linear" conformity of the methylene groups is compensated, one for the other, by the two sulfur atoms. In cystathionine, the single sulfur atom induces a sharp "bend" in the structure. Granted that movement and rotation are possible between the atoms, this difference in configuration could explain the failure of cystathionine to be involved in the mechanism of Dent and Rose (7). The high clearance ratios of the asymmetrical disulfide of cysteine and homocysteine in cystinuria and of the disulfide of D-penicillamine and L-cystine, the latter observed after therapy of cystinuria with D-penicillamine (11), are compatible with this concept.

\section{References}

1. Harris, H., L. S. Penrose, and D. H. H. Thomas. Cystathioninuria. Ann. hum. Genet. 1959, 23, 442.

2. Frimpter, G. W., A. Haymovitz, and M. Horwith. Cystathioninuria. New Engl. J. Med. 1963, 268, 333.

3. Berlow, S. Studies in cystathioninemia. Amer. J. Dis. Child. 1966, 112, 135.

4. Mongeau, J.-G., M. Hilgartner, H. G. Worthen, and G. W. Frimpter. Cystathioninuria: study of an infant with normal mentality, thrombocytopenia, and renal calculi. J. Pediat. 1966, 69, 1113.

5. Gjessing, L. R. Studies of functional neural tumors. II. Cystathioninuria. Scand. J. clin. Lab. Invest. 1963, 15, 474.

6. Brenton, D. P., D. C. Cusworth, and G. E. Gaull. Homocystinuria. Biochemical studies of tissues including a comparison with cystathioninuria. Pediatrics 1965, 35, 50.

7. Dent, C. E., and G. A. Rose. Aminoacid metabolism in cystinuria. Quart. J. Med. 1951, 20, 205.

8. Robson, E. B., and G. A. Rose. The effect of intravenous lysine on the renal clearances of cystine, arginine and ornithine in normal subjects, in patients with cystinuria and Fanconi syndrome and in their relatives. Clin. Sci. 1957, 16, 75.

9. Doolan, P. D., H. A. Harper, M. E. Hutchin, and E. L. Alpen. Renal clearance of lysine in cystinuria; pathogenesis and management of this abnormality. Amer. J. Med. 1957, 23, 416.

10. Frimpter, G. W. Cystinuria: metabolism of the disulfide of cysteine and homocysteine. J. clin. Invest. 1963, 42, 1956.

11. Crawhall, J. C., E. F. Scowen, and R. W. E. Watts. Effect of penicillamine on cystinuria. Brit. med. J. 1963, 1, 588.

12. Asatoor, A. M., B. W. Lacey, D. R. London, and M. D. Milne. Amino acid metabolism in cystinuria. Clin. Sci. 1962, 23, 285. 
13. Milne, M. D., D. R. London, and A. M. Asatoor. Citrullinuria in cases of cystinuria. Lancet 1962, 2, 49.

14. Scriver, C. R. Personal communication.

15. Frimpter, G. W. Cystathioninuria in The Metabolic Basis of Inherited Disease, 2nd ed., J. B. Stanbury, J. B. Wyngaarden, and D. S. Fredrickson, Eds. New York, McGraw-Hill, 1966, p. 409.

16. Stein, W. H., and S. Moore. The free amino acids of human blood plasma. J. biol. Chem. 1954, 211, 915.

17. Spackman, D. H., W. H. Stein, and S. Moore. Automatic recording apparatus for use in the chromatography of amino acids. Analyt. Chem. 1958, 30, 1190.

18. Frimpter, G. W., M. Horwith, E. Furth, R. E. Fellows, and D. D. Thompson. Inulin and endogenous amino acid renal clearances in cystinuria: evidence for tubular secretion. J. clin. Invest. 1962, $41,281$.
19. Schreiner, G. E. Determination of inulin by means of resorcinol. Proc. Soc. exp. Biol. (N. Y.) 1950, 74, 117.

20. Walser, M., D. G. Davidson, and J. Orloff. The renal clearance of alkali-stable inulin. J. clin. Invest. 1955, 34, 1520.

21. Webber, W. A., J. L. Brown, and R. F. Pitts. Interactions of amino acids in renal tubular transport. Amer. J. Physiol. 1961, 200, 380.

22. Schwartzman, L., A. Blair, and S. Segal. A common renal transport system for lysine, ornithine, arginine and cysteine. Biochem. biophys. Res. Commun. 1966, 23, 220.

23. Goresky, C. A., H. Watanabe, and D. G. Johns. The renal excretion of folic acid. J. clin. Invest. 1963, 42, 1841.

24. Crawhall, J. C., and C. J. Thompson. Renal secretion of cystine in cystinuria (abstract). J. clin. Invest. 1965, 44, 1038. 